\title{
The influence of service quality of motor vehicle tax toward taxpayer compliance in paying motor vehicle tax (a case study at Samsat Lubuk Linggau)
}

\author{
Y Marliza $^{1 *}, \mathrm{KY}$ Wiguna $^{1}$, and MR Andini ${ }^{1}$ \\ ${ }^{1}$ Program Studi Akuntansi Fakultas Ekonomi Universitas Musi Rawas \\ *Corresponding author: marlizayayuk77@gmail.com
}

\begin{abstract}
This study aims to determine the influence of service quality of motor vehicle tax toward taxpayer compliance in paying motor vehicle tax (a case study at SAMSAT Lubuk Linggau). This research is quantitative. The operational variables of this study are the quality of the service of motor vehicle tax and motor vehicle taxpayer compliance. The data source used in this study is primary and secondary data. The population of this study is 63.218 registered taxpayers compliance of 2019 in SAMSAT Lubuk Linggau. The sample of this study is 100 respondents from 63.218 registered taxpayers' compliance. The data analysis technique used is a descriptive quantitative analysis by using simple linear regression. The results showed that the results of the T-test analysis partially influence the independent variable on the dependent variable where $\mathrm{T}$ count $>\mathrm{T}$ table (3.394>1.289) with a significant value of $0.001<0.10$ by means "Ho is rejected and Ha accepted". The value of the determinant coefficient (R2) in this study is 0.105 or $10.5 \%$ by means a change occurred in Taxpayer Compliance (Y) through service quality (X) of 10.5 percent, while the remaining 89.5 percent is derived by other external factors such as taxpayer knowledge, taxpayer awareness about its importance, taxpayer penalties, and SAMSAT Drive-Thru system (vehicle registration and payment service outside SAMSAT building).
\end{abstract}

\section{Introduction}

One of the important revenue for the regional government is regional tax. Regulation number 28 of 2009 article 2 states that there are five types of provincial taxes which consist of motor vehicle tax, title transfer vehicle tax, environmental tax, surface water tax, and cigarette tax. The motor vehicle tax collection system requires public support and participation in the form of compliance to pay taxes. One of the contributions for developing this country is taxpayer compliance that adopts a selfassessment system through calculating, payment, and reporting the tax.

Based on the observation results at the SAMSAT office of Lubuklinggau City seen from the realization of Motor Vehicle Tax revenue from 2016 to 2019, Motor Vehicle Tax in 2015 did not reach the target because the realization tax was Rp. 41,104,078,806.00, while the predetermined target was Rp. $47,343,140,106.00$ or $86.82 \%$. The realization tax revenue in 2016 was Rp. $45,851,045,728.00$ while the predetermined target was IDR $57,533,984,715.00$ or $79.69 \%$. In 2017 , the realization of Motor Vehicle Tax revenue did not reach the target with Rp.51,774,335,552.00 while the target was Rp. 55,552,903,860, however, the achievement is increased by $93.20 \%$. In 2018 the realization of Motor Vehicle Tax revenue reached the target and even exceeded the predetermined 
target of Rp. 56,050,503,927.00 or 103.84 percent while the target was Rp.53,979,300,000.00. In 2019, the achievement of the Motor Vehicle Tax target increased again with Rp.60,015,308,961.00 while the target was Rp. $54,136,516,000.00$ or $110.88 \%$. Thus this study focuses on the influence of service quality of motor vehicle tax toward tax compliance in paying motor vehicle tax at SAMSAT office Lubuk Linggau.

Tax imposition in Indonesia can be grouped into two parts, namely: State Tax and Local Tax [4]. State taxes that are currently in effect are Income Tax (PPh), Value Added Tax (PPN) and Sales Tax on Luxury Goods (PPN \& PPnBM), Stamp Duty. Meanwhile, Regional Taxes are divided into 2 parts, namely: Provincial Taxes and Regency / City Taxes.

The quality of tax services is an optimal service provision that giving optimal satisfaction for taxpayers. Quality services must be able to provide $4 \mathrm{~K}$, namely security, comfort, continuity, and legal certainty. Service quality can be measured by the ability to provide satisfactory service through responses, abilities, politeness, and trustworthiness from tax officials, establish good communication, understand the needs of taxpayers, provide adequate communication facilities, and employees who are competent in their duties [3]

Motor Vehicle Tax is a vehicle's ownership tax. Motorized vehicles are all wheeled vehicles that are used on all types of land roads, and are driven by technical equipment in the form of a motorbike or other equipment which functions to convert a certain energy resource into movement including heavy equipment and large equipment that uses wheels and temporarily attached motorbikes as well as motorized vehicles operated in water.[5]

Taxpayer compliance is a tax fulfillment to contribute to the development of the country. [6] Tax compliance is a compliance climate and awareness of the tax fulfillment in a situation where taxpayers understand tax regulation, registration, calculation, and tax payment. There are two types of compliance, namely: 1) Formal compliance is a condition in which the taxpayer fulfills their obligations formally by the tax regulation. 2) Material compliance is a condition in which the taxpayer substantially or essentially fulfills all material tax provisions in accordance to tax regulation namely regulation number 18 of 1997 about regional tax and regional retribution changed into regulation number 34 of 2000 and government regulation number 65 of 2001 about regional tax. [7]

[2] Defines a compliant taxpayer is a taxpayer who is determined by the Director-General of Taxes as a taxpayer who meets certain criteria, namely:

1) Be on time in submitting the Tax Return, including:

(a) Submission of Annual Tax Returns on time within the last 3 (three) years.

(b) Submission of Periodic Tax Returns late in the last year for the tax period January to November is not more than 3 (three) Tax Periods for each type of tax and not consecutive.

2) Do not have tax arrears for all types of taxes, except for tax arrears that have obtained permission to pay installments or postpone tax payments, covering the situation on December 31 of the year before the determination as a Compliant Taxpayer and excluding tax payable which has not passed the deadline for a settlement.

3) Never been convicted of committing a criminal offense in the tax department based on a court decision that has permanent legal force within the last 5 (five) years.

\section{Material and Method}

The type of this research is quantitative research. This research is conducted to determine the "effect" among variables. This research is conducted at the SAMSAT Office of Lubuklinggau. The populations of this study are registered motor vehicle taxpayers at SAMSAT Lubuklinggau Office of 2019that reaches 63,218 people. Based on the Slovin formula, the sample of this study is 100 respondents. Data of this study is the number of Motor Vehicle Taxpayers who re-register and are in arrears, and the realization of local tax revenue from the Motor Vehicle Tax (PKB) 2019 from the SAMSAT office of Lubuklinggau. The data collection methods used in this study are questionnaires and document analysis. 
The data analysis technique for this research is simple regression analysis through simple linear regression equation model and regression equation model: $\mathrm{Y}=\mathrm{a}+\mathrm{bX}$ [1]. Simple regression testing of this study uses a significance level of 5\% therefore decision making as follows:

- Ho: there is no significant effect between the quality of Motor Vehicle Tax services variable toward taxpayer compliance variable in paying Motor Vehicle Tax

- Ha: there is a significant effect between the quality of Motor Vehicle Tax services variable toward taxpayer compliance variable in paying Motor Vehicle Tax

\section{Result And Discussion}

Based on the questionnaire result, the total value of the indicator tax fulfillment is 420 or 56 percent agreed by means taxpayers have paid motor vehicle tax. The total value of the indicator paying tax on time is 356 or 53 percent agreed by means taxpayers pay taxes on time. The total value of the indicator feasible taxpayer is 418 or 60 percent agreed by means taxpayers complete the data requirements for motor vehicle tax payments. The total value of the indicator due date of payment is 317 or 47 percent agreed by means taxpayers often forget the due time of motor vehicle tax payment.

The results of data processing variable $X$ (service quality of motor vehicle tax) and variable data $Y$ (motor vehicle taxpayer compliance) with the IBM SPSS Version 20 (results of the simple linear regression equation)are in the following table:

\section{Coefficients}

\begin{tabular}{|c|c|c|c|c|c|c|}
\hline \multirow[t]{2}{*}{ Mode } & & \multicolumn{2}{|c|}{$\begin{array}{c}\text { Unstandardized } \\
\text { Coefficients } \\
\end{array}$} & \multirow{2}{*}{$\begin{array}{c}\text { Standardized } \\
\text { Coefficients } \\
\text { Beta } \\
\end{array}$} & \multirow[t]{2}{*}{$\mathrm{T}$} & \multirow[t]{2}{*}{ Sig. } \\
\hline & & $\mathrm{B}$ & Std. Error & & & \\
\hline \multirow{3}{*}{1} & (Constant) & 7.814 & 2.160 & \multirow{3}{*}{.324} & \multirow[t]{2}{*}{3.618} & \multirow[t]{2}{*}{.000} \\
\hline & Quality & \multirow{2}{*}{.133} & \multirow{2}{*}{.039} & & & \\
\hline & & & & & 3.394 & .001 \\
\hline
\end{tabular}

a. Dependent Variable: Tax Compliance

Furthermore, from the results of the regression analysis above, it is obtained a simple linear regression equation in this study is: $\mathrm{Y}=7,814+0.133 \mathrm{X}$

The analysis of the regression equation above is:

- The constant value of the regression equation in this study is 7,814 which proves that if the independent variable (service quality) is assumed to be constant (constant) thus the value of the dependent variable (taxpayer compliance) is 7.814 .

- The value of coefficient variable $X$, if the quality of service has been increased by one, thus the compliance is increased by 0.133 assuming the other variables were constant.

Based on the results of the t-test, partially the effect of the independent variable on the dependent variable is based on the analysis of the quality of tax services, the value of $t$-count $>t$-table is 3.394> 1.289 with a significant value of $0.001<0.10$ by means Ho is rejected and $\mathrm{Ha}$ is accepted by means there is a significant effect between the quality of the tax service toward taxpayer compliance with the assumption other variables are constant,

Based on the results of the t-test, partially the effect of the independent variable on the dependent variable is based on the analysis of the quality of tax services, the value of $t$-count $>t$-table is 3.394> 1.289 with a significant value of $0.001<0.10$ by means Ho is rejected and Ha is accepted by means there is a significant effect between the quality of the tax service toward taxpayer compliance with the assumption other variables are constant.

Furthermore, it can be explained that the highest indicator is physical evidence (tangibles), supported by the registration that is available properly and completely but less comfortable. The 
lowest indicator is empathy because average respondents feel the officers are less friendly and attention to problems faced by taxpayers. The coefficient of determination (R2) is only 10.5 percent by means the insufficient ability in explaining taxpayer compliance. To increase the value of the quality of motor vehicle tax services at SAMSAT Lubuklinggau, it is necessary to make better efforts to improve the quality of motor vehicle taxpayer compliance.

\section{Conclusion}

The conclusions in this research are: Based on the $t$-test, the value of $t$ count $>t$ table is $3.394>1.289$ with a significant value of $0.001<0.10$ by means Ho is rejected and $\mathrm{Ha}$ is accepted which means there is a significant effect between the quality of tax service and taxpayer compliance by assuming the other variables are constant; and The value of the determinant coefficient (R2) in this study is 0.105 or $10.5 \%$ by means a change occurred in Taxpayer Compliance $(\mathrm{Y})$ through service quality $(\mathrm{X})$ of 10.5 percent, while the remaining 89.5 percent is derived by other external factors such as taxpayer knowledge, taxpayer awareness about its importance, taxpayer penalties, and SAMSAT Drive-Thru system (vehicle registration and payment service outside SAMSAT building).

\section{References}

[1] Danang Sunyoto. 2016. Methodologi Penelitian Akuntansi. Bandung: PT Rafika Aditama

[2] Fidel. 2015. Administrasi Perpajakan. Jakarta: Salemba Empat.

[3] Ishak, Sitti, danWa Ode. 2017. Pengaruh Kualitas Pelayanandan Kepuasan Wajib Pajak Terhadap Kepatuhan Membayar Pajak Kendaraan Bermotor (StudiKasus Kantor Bersama Sistem Administrasi Manunggal di Bawah Satu Atap (SAMSAT) Kendari).Jurnal Akuntansi dan Keuangan. Volume II/2/Oktober 2017. ISSN (Online):2503-1635, ISSN (Print):2088-4656. Fakultas Ekonomi dan Bisnis Universitas Halu Oleo Kendari Sulawesi Tenggara.

[4] Mardiasmo. 2013. Perpajakan Edisi Revisi. Yogyakarta: Andi.

[5] Marihot Pahala Siahaan. 2013. Pajak daerah dan Retribusi Daerah. Berdasarkan Undangundang Nomor 28 Tahun 2009 Tentang Pajak Daerah dan Retribusi Daerah. Jakarta; RajawaliPers

[6] Mujiyati.2014. Hukum Pajak dan Perpajakan. Jakarta: Salemba Empat.

[7] UU Nomor 28 Tahun 2009 Pasal 2 tentang Pajak dan Retribusi Daerah. 